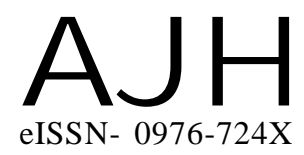

Article history :

Received : 22.01.2016

Accepted : 30.05.2016
Members of the Research Forum

Associated Authors:

${ }^{1}$ Indian Institute of Horticultural

Research, BENGALURU

(KARNATAKA) INDIA

${ }^{2}$ College of Horticulture, University of Horticulture Science Campus,

G.K.V.K., BENGALURU

(KARNATAKA) INDIA

${ }^{3}$ Dr. Y.S.R. Horticulture University, VENKATARAMANNAGUDEM (A.P.) INDIA
Author for correspondence : H.K. PORIKA

College of Horticulture, University of Horticulture Science Campus,

G.K.V.K., BENGALURU

(KARNATAKA) INDIA

Email : harikanthporika@gmail.com
THEASIAN JOURNALOF HORTICULTURE

Volume 11 | Issue 1 | June, 2016 | 252-260

Visit us -www.researchjournal.co.in

\title{
Graft compatibility-incompatibility in fruit crops: Mechanism and determination techniques
}

\section{H.K. PORIKA, P.K. NIMBOLKAR ${ }^{1}$, B. RAJASHEKAR ${ }^{2}$ AND S. FIROZ HUSSAIN $^{3}$}

ABSTRACT : Commercial fruit trees are usually formed by the combination of a rootstock and a scion to broaden the adaptability of scion cultivars to soil and climatic conditions, facilitate agricultural management, and/or increase productivity. In general, closely related cultivars and species tend to be compatible, but taxonomically distant plants often manifest incompatibility. The physiological, metabolic and molecular mechanisms that cause incompatibility remain unclear and several hypotheses have been proposed to explain it, mostly based on herbaceous species. We sum up different reasons that may have an influence on graft success: inherent system of cellular incompatibility, formation of plasmodesmata, vascular tissue connections, and the presence of growth regulators and peroxidases. Understanding the spatial organization of the graft interface is important to the evaluation of new rootstock genotypes and to the development of new grafting technologies. An early and accurate prediction of graft incompatibility has great importance because incompatible combinations could be avoided while compatible ones could be selected. The complexity of incompatibility and the mechanism behind the reactions have been investigated in several ways. More research is needed to fully understand the mechanism of graft incompatibility, particularly in woody plants. This knowledge is essential to develop molecular markers useful in rootstock breeding programmes.

KEY WORDS : Graft compatibility/incompatibility, Callus, Plasmodesmata, Electrophorosis, $\mathrm{X}$-ray tomography, Phenol

HOW TO CITE THIS ARTICLE : Porika, H.K., Nimbolkar, P.K., Rajashekar, B. and Hussain, S. Firoz (2016). Graft compatibility-incompatibility in fruit crops: Mechanism and determination techniques. Asian J. Hort., 11(1) : 252-260, DOI : 10.15740/HAS/TAJH/11.1/252-260. 